\title{
Uji Event Studies: Dampak Peristiwa Aksi Bela Islam (Aksi 212) Terhadap Abnormal Return dan Trading Volume Activity
} (Saham Syariah di Jakarta Islamic Index)

\author{
Nor Hadi \\ IAIN Kudus \\ nh_oke@yahoo.co.id \\ Arum Mediyawati \\ IAIN Kudus \\ Arummediyawati6@gmail.com
}

\begin{abstract}
Abstrak
Artikel ini ditujukan untuk menguji teori efficiency market hypothesis dalam pasar bentuk lemah lewat event studies. Pengujian empiris dalam bentuk response inventor atas kejadian aksi demonstrasi besar-besaran kaum muslimin atas dugaan penistaan agama yang terkenal dengan nama aksi 212. Pengujian response investor, berupa apakah aksi 212 mempengaruhi volatilitas abnormal return dan trading volume activity saham syari'ah yang tergabung dalam Jakarta Islamic Index. Data penelitian adalah data sekunder yaitu return saham, harga saham, index harga saham, dan abnormal return saham syari'ah, dengan periode pengamatan 15 hari sekitar tanggal kejadian aksi 212. Untuk memperoleh data digunakan prosedur dokumentasi. Jumlah perusahaan yang dimasukkan dalam unit analisis sebanyak 26 perusahaan. Data dianalisis dengan statistik Paired Sample t-Test. Hasil pengujian hipotesis dengan data empiris menunjukan bahwa hipotesis pertama bahwa terdapat perbedaan rata-rata abnormal return sebelum dan sesudah aksi 212 adalah signifikan diterima. Sementara, hipotesis kedua bahwa terdapat perbedaan rata-rata trading volume activity sebelum dan sesudah aksi 212 menghasilkan tidak signifikan (ditolak). Hasil pengujian hipotesis tersebut menunjukkan bahwa investor merespon aksi 212 dalam bentuk volatilitas harga saham sehingga abnormal return secara nyata berbeda sesudah dan sebelum aksi 212. Bentuk respons tersebut juga ditunjukkan dengan sikap wait and see, sehingga aktive Trading sekitar tanggal aksi 212 dan sesudah aksi 212 cenderung menurun atau stagnan.
\end{abstract}

Keywords: efficiency market hypothesis, event studies, return saham, abnormal return, trading volume activity 


\begin{abstract}
This article is intended to test the theory of market efficiency hypotheses in weak forms through event studies. Empirical testing in the form of investor response to the massive Muslim demonstration over alleged blasphemy known as action 212. Investors' response testing, in the form of whether the 212 action affects the volatility of abnormal returns and the trading volume of shari'ah stock activity incorporated in Jakarta Islamic Index. The research data are secondary, namely stock returns, stock prices, stock price indexes and sharia stock abnormal returns, with an observation period of 15 days around the date of the action event 212. Data collection by documentation procedures. The number of companies included in the analysis are 26 companies. Data were analyzed using Paired Sample t-Test statistics. The results of testing the hypothesis with empirical data show that the first hypothesis that there are differences in the average abnormal return before and after the 212 action is significantly accepted. Meanwhile, the second hypothesis that there are differences in average trading volume activity before and after the 212 action does not significant (rejected). The results of testing the hypothesis indicate that investors respond to 212 actions in the form of stock price volatility so that abnormal returns are significantly different after and before the 212 action. The response form is also indicated by a wait and see attitude, so that active trading around the 212 action date and after 212 action tends decrease or stagnate.
\end{abstract}

Keywords: efficiency market hypothesis, event studies, stock return, abnormal return, trading volume activity

\title{
A. PENDAHULUAN
}

Investor merupakan pihak yang rasional, sehingga keputusan investasi yang diambil diharapkan memberikan keuntungan ${ }^{1}$. Investasi merupakan keputusan sekarang untuk memperoleh keuntungan tertentu di masa datang yang serba tidak menentu ${ }^{2}$. Sesuai karakternya (future Time), investasi mengandung probabilitas atau risiko ${ }^{3}$, oleh karena setiap

\footnotetext{
${ }^{1}$ Hadi. Nor, 2017, Pasar Modal, Graha Ilmu, Yogyakarta, Indonesia.

${ }^{2}$ Dyl, Edward A, Maberly, Edwin D, 1988, A Possible Eplantion of The Weeken Effect, Financial Analysis Journal, Vol. 44, Issue. 33.

${ }^{2}$ Suryawijaya, Marwan Asri, dan Faizal Arief Setiawan. 1998, Reaksi Pasar Modal terhadap Peristiwa Politik dalam Negeri (Event Studies pada Peristiwa 27 Juli 1996), KELOLA VII, No. 18.

${ }^{3}$ Qian Sun, Wison. H. S. Tong, Jing Tong, 2003, How Daes Government Ownership Affect Firm Performance? Evidence from China's Privatizations Experience, Journal of Business \& Accounting, Vol 29, Issue 1-2, pp. 1-27.

${ }^{3}$ Vong, A. P. I., \& Trigueiros, D., 2010, The short-run price performance of initial public offerings in Hong Kong: New evidence, Global Finance Journal, Vol. 21, No. 3, Pp. 253-261.
} 
keputusan investasi hendaknya didukung oleh informasi yang cukup dan akurat untuk mengurangi kandungan risiko ${ }^{4}$.

Investor membutuhkan informasi untuk menekan probabilitas risk of investment ${ }^{5}$. Kemampuan menekan risk, memberikan ruang besar dalam meningkatkan emotional decission sehingga secara psikologis investor dapat mengurangi tekanan dalam mengambil keputusan $^{6}$. Tandelilin berpendapat bahwa kemampuan analisis keputusan investasi merupakan satu cara bagi investor dalam mengambil keputusan ${ }^{7}$. Analisis investasi ini dapat didasarkan pada kontektualitas keuangan perusahaan maupun analisis lingkungan baik mikro, makro, politik, industri, maupun event-event penting lainnya (fundamental analysis), maupun analisis teknikal ${ }^{8}$. Brown \& Warner menyatakan bahwa analisis fundamental yang didasarkan pada laporan keuangan perusahaan mengandung information content sehingga dapat digunakan untuk analisis dan rangka mengurangi potensi risk probability $^{9}$.

Disamping fundamental analysist, investasi di pasar modal juga dapat dibantu dengan analisis teknikal ${ }^{10}$. Analisis teknikal pada dasarnya merupakan upaya pencarian pola perulangan yang dapat diprediksi lewat harga saham ${ }^{11}$. Gerakan harga saham memberikan informasi tentang kecenderunga, sifilis, habutausi gerakan sehingga memberikan informasi pola harga saham dilantai bursa ${ }^{12}$. Gerakan saham dapat dijelaskan dengan aksi lingkungan, seperti kondisi ekonomi, keamanan, serta event sosial yang

${ }^{4}$ Peter, S., 2015, Explaining Short Run Performance of Initial Public Offerings in an Emerging Frontier Market: Case of Sri Lanka, International Journal of Economics, Business and Finance, Vol. 3, No. 1, Pp. 1-13.

4. Perera, W., \& Kulendran, N., 2016, Evaluation of Short-Run Market Performance and its Determinants Using Marginal Analysis and Binary Models: Evidence from Australian Initial Public Offerings, Journal of Insurance and Financial Management, Vol. 2, No. 6, pp. 1-29.

${ }_{5}$ Mian Sajid Nazir, Hassan Younus, Ahmad Kaleem \& Zeshan Anwar, 2014, Impact of political events on stock market returns: empirical evidence from Pakistan, Journal of Economic and Administrative Sciences, Vol. 30, No. 1, pp. 60-78.

${ }^{6}$ Aktas, H. and Oncu, S., 2006, The stock market reaction to extreme events: the evidence from Turkey, International Research Journal of Finance and Economics, Vol. 6, No. 6, pp. 78-85.

${ }^{7}$ Tandelilin, Eduardus, 2010, Portofolio \& Investasi Teori dan Aplikasi, Edisi Pertama, Yogyakarta, Kanisius IKAPI.

${ }^{8}$ Chiu, C.L., Chen, C.D. and Tang, W.W., 2005, Political elections and foreign investor trading in South Korea's financial markets, Applied Economics Letters, Vol. 12, No. 11, pp. 673-677

${ }^{9}$ Brown, S. and Warner, J., 1985, Using daily stock returns in event studies, Journal of Financial Economics, Vol. 14, No. 1, pp. 3-31.

${ }^{10}$ Ferguson, N., 2006, Political risk and the international bond market between the 1848 revolution and the outbreak of the First World War, Economic History Review, Vol. 59, No. 1, pp. 70-112

${ }^{11}$ Halim, Abdul, 2015, Analisis Investasi dan Aplikasinya, Jakarta. Salemba Empat

12 Bechtel, M.M., 2009, The political sources of systematic investment risk: lessons from a consensus democracy, The Journal of Politics, Vol. 71, No. 2, pp. 661-677. 
mempengaruhi psikologis pelaku pasar ${ }^{13}$. Vong, A. P. I., \& Trigueiros berpendapat bahwa pelaku pasar cenderung menghendaki kondisi lingkungan dan stabil, dan berusaha wait and see atas kondisi politik dan keamanan yang kurang menentu ${ }^{14}$. Perilaku investor tersebut pada giiliranya akan menentukan tingkat volatilitas permintaan.

Peristiwa aksi 212 tahun 2016 merupakan peristiwa besar yang dapat dijadikan prototipe fundamental yang dapat memicu reaksi pasar. Aksi 212 memiliki power besar menggerak massa secara nasional sehingga rentan terhadap stabilitas politik, keamanan dan ekonomi. Hal itu merupakan fundamental ekonomi yang memiliki kerentanan terhadap volatilitas kinerja pasar ${ }^{15}$. Gerakan semakin membesar dan sulit dibendung karena menyentuh hak Asasi Agama (sentimen agama). Kampanye oleh salah satu kandidat gubernur DKI Jakarta (30 September 2016 di Kepulauan Seribu), menyinggung umat Islam termasuk aktor fundamental. Dampak dari kejadian itu, ormas Islam mengadakan demo pada tanggal 2 Desember 2016 yang diberi nama aksi 212. Peristiwa tersebut menyita perhatian masyarakat Indonesia bahkan sampai ke luar negeri, sehingga berpotensi mengoreksi kinerja pasar.

Riset terkait peran faktor lingkungan (seperti peristiwa 2012) dijelasan kerangka pikir efficiency market hyphotesis, yaitu even studies. Anatomi event studies menjelaskan bahwa pergerakan saham, harga saham, ubnormal return, risko investasi, dapat mempengaruhi emotional investor sehingga mimunculkan perilaku baru dalam keputusan investasi. Hal itu dapat berakibat pada terkoreksinya harga, return, risiko dan sejenisnya disekitar peristiwa tertentu ${ }^{16}$. Masood \& Sergi menyatakan bahwa studi terkait event studies yang mengkaitkan kejadian tertentu terhadap pergerakan saham, return, abnormal return dan sejenisnya merupakan bentuk anomali pasar yang merupakan penyimpangan dari hipotesis pasar efisien ${ }^{17}$. Beberapa penelitian terkait anomali pasar tersebut, seperti: january effect, size effect, low P/E ratio, winner loser anomaly, suksesi nasional effect,

${ }^{13}$ Husnan, Suad, 2003, Dasar-dasar Teori Portofolio dan Analisis Sekuritas. Yogyakarta: AMP YKPN.

${ }^{14}$ Vong, A. P. I., \& Trigueiros, D., 2010, The short-run price performance of initial public offerings in Hong Kong: New evidence. Global Finance Journal, Vol. 21. No. 3, pp 253-261.

${ }^{15}$ Ismail, I. and Suhardjo, H., 2001, The impact of Domestic political events on an emerging stock market: the case of Indonesia, Proceedings of Asia Pacific Management Conference, pp. 235-262.

16 Jorion, P. and Geotzmann, W.N., 1999, Global stock markets in the twentieth century, Journal of Finance, Vol. 54, No. 3, pp. 953-980.

${ }^{17}$ Masood, O. and Sergi, B.S., 2008, How political risks and events have influenced Pakistan's stock markets from 1947 to present, Economic Policy in Emerging Economies, Vol. 1, No. 4, pp. 427-444. 
monday effect, dan sejenisnya ${ }^{18}$. Chiu, Chen and Tang menunjukkan bahwa monday effect di pasar Amerika Serikat adalah terkonsentrasi pada dua senin terakhir setiap bulannya, dimana, hal itu muncul akibat adanya tuntutan likuiditas investor individual menjelang akhir bulan yang menyebabkan tekanan penjualan menjadi tinggi ${ }^{19}$. Antaraiksa menunjukkan bahwa return pada hari senin cenderung terjadi return negatif, begitu juga pada hari Jumat sebelumnya ${ }^{20}$.

Penelitian ini dimaksudkan untuk menguji event studies yang dalam hal ini adalah tingkat sensifitas peristiwa 212 dalam mempengaruhi perilaku investor yang dalam hal ini di tunjukkan dengan tingkat volatilitas abnormal return dan trading volume activity. Logika yang mendasari pengujian peristiwa 212 bahwa peristiwa tersebut berskala nasional bahkan menjadi perhatian publik internasional. Peristiwa tersebut memiliki kerentanan sosial dan keamanan, sehingga para pelaku pasar akan bertidak wait and see. Tindakan invstor tersebut berdampak pada reaksi pasar yang ditunjukkan dengan volum trading activity, volatilitas harga sekuritas, abnormal return, dan sejenisnya. Abnormal return terjadi karena adanya informasi baru yang mengubah nilai perusahaan dan direaksi oleh investor dalam bentuk kenaikan atau penurunan harga pasar. Jika suatu pengumuman mengandung informasi, maka pasar akan menerima abnormal return, dan sebaliknya jika suatu peristiwa tidak mengandung informasi maka pasar tidak akan menerima abnormal return ${ }^{21}$.

${ }^{18}$ Cahyaningdyah, D, 2005, Analisis Pengaruh Hari Perdagangan Terhadap Return Saham: Pengujian Week-Four Effect dan RogalskiEffect di Bursa Efek Jakarta. Jurnal Ekonomidan Bisnis Indonesia, Vol.20, No.2, hal.175-186.

${ }^{17}$ Dyl, Edward A, Maberly, Edwin D, 1988, A Possible Eplantion of The Weeken Effect, Financial Analysis Journal, Vol. 44, No. . 33.

${ }^{17}$ Setiyo, I \& Nurhatmini, E., 2003, Pengaruh Hari Perdagangan dan Exchange Rate terhadap Return Saham di BEI. Jurnal Wahana, Vol.6, No.1.

${ }^{17}$ Murtini, U. \& Halomoan.A.I., 2007, Pengaruh HariPerdagangan terhadap Return Saham:Pengujian Monday, Week-Four, dan Rogalski Effect di Bursa Efek Jakarta, Jurnal Riset Akuntansi dan Keuangan. Vol.3, No.1, pp. 20-33.

17 Miller, 1988, The Modigliani-Miller Propositions after Thirty Years, Journal of Economic Perspective, Vol. 2, No. 4, pp.99-120.

${ }^{19}$ Chiu, C.L., Chen, C.D. and Tang, W.W., 2005, Political elections and foreign investor trading in South Korea's financial markets, Applied Economics Letters, Vol. 12 No. 11, pp. 673-677.

${ }^{20}$ Antariksa, B., 2005, Fenomena The Monday Effectdi Bursa Efek Jakarta, Simposium Nasional Akuntansi VII. Solo

${ }^{21}$ Brown, S. and Warner, J., 1985, Using daily stock returns in event studies, Journal of Financial Economics, Vol. 14, No. 1, pp. 3-31.

${ }^{21}$ Feils, D.A., 2000, The impact of political risk on the foreign direct investment decision: a capital budgeting analysis, Emerging Economist, Vol. 45, No. 2, pp. 129-143.

${ }^{21}$ Mackinlay, A., 1997, Event studies in economics and finance, Journal of Economics Literature, Vol. 35, No. 1, pp. 13-35. 
Berdasar logika teoritik tersebut diatas, dapat dihipotesiskan bahwa "Peristiwa 212 mengoreksi perilaku investor sehingga memunculkan perilaku baru investor dalam bentuk perbedaan abnormal return dan volume trading activity sebelum dan sesudah peristiwa $212 "$.

\section{B. METODE PENELITIAN}

\section{Pendekatan \& Jenis Data Penelitian}

Penelitian menggunakan pendekatan positivistik kuantitatif, yang mana, dimaksudkan untuk menguji teori yaitu Efficiency Market Hyphotesis dalam hal ini pasar bentuk lemah, yaitu event studies. Uji event studies dalam penelitian ini adalah menguji dampak peristiwa 212 terhadap reaksi pasar yaitu dengan uji beda abnormal return dan volume trading activity di lantai bursa sebelum dan sesudah peristiwa 212.

Jenis data yang digunakan dalam penelitian ini adalah data sekunder yaitu data terkait dengan return saham, harga saham, volume trading saham dan index harga saham gabungan perusahaan go publik yang saham-nya masuk dalam kelompok Jakarta Islamic Index (JII). Untuk memperoleh data digunakan prosedur dokumentasi, sedang teknik sampling yang digunakan adalah purposive random sampling. Jumlah sampel dalam penelitian ini sesuai adegan kriteria yang ditetapkan sebanyak 26 perusahaan.

\section{Operasional variabel}

Tedapat jenis varriabell penelitian, yaitu: (1) abnormal rerurn, selisih reurn yang diharapkan dengan retur yang ssesungguhnya; dan (2) Trading volume activity, pergerakan aktivitas volume perdagangan saham pada periode tertentu ${ }^{22}$. Adapun untuk memberikan gambaran operasional variabel dijelaskan sebagai berikut:

1. Menghitung Abnormal Return

a. Menghitung Return Sesunggguhnya atau Return Realisasi (Actual Return)

Perhitungan actual return digunakan selisih harga relatif sekarang terhadap harga sebelumnya yang diformulasikan sebagai berikut:

${ }^{22}$ Mackinlay, A., 1997, Event studies in economics and finance, Journal of Economics Literature, Vol. 35, No. 1, pp. 13-35

${ }^{22}$ Hari Prasetyo, 2006, Analisis Pengaruh Hari Perdagangan Terhadap Return, Anbormal Return, Dan Volatilitas Return Saham (Studi Pada LQ 45 Periode Januari-Desember 2005), Tesis, Universitas Diponegoro, Unplusished., 33 
Rit $=\frac{P_{i t}-P_{i t-1}}{P_{i t-1}}$

Dimana:

$\mathrm{R}_{\mathrm{it}}=$ return realisasi sekuritas ke-i pada periode ke $\mathrm{t}$

$\mathrm{P}_{\text {it }}=$ harga sekuritas sekarang relatif

$\mathrm{P}_{\mathrm{it}-1}=$ harga sekuritas hari sebelumnya

Dalam hal ini harga yang dimaksud adalah harga saham sekuritas ke-i saat penutupan bursa (closing price) pada saat periode ke-t.

b. Menghitung Return Ekspektasian (Expected Return)

Cara menghitung expected return saham menggunakan pendekatan model pasar yang disesuaikan (market adjusted model), yaitu dengan menghitung tingkat pengembalian portofolio pasar harian yang bisa diwakili dengan IHSG sebagai berikut: ${ }^{23}$

$R_{M t}=\frac{\text { Indeks } J I_{t}-\text { Indeks } J I_{t-1}}{\text { Indeks } J I_{t-1}}$

Dimana:

$\mathrm{R}_{\mathrm{Mt}}=$ Return pasar periode peristiwa ke- $\mathrm{t}$

Indeks JII $I_{t}=$ Indeks pasar JII pada periode $\mathrm{t}$ (sekarang)

Indeks JII $\mathrm{t}_{-1}=$ Indeks pasar JII pada periode ke $\mathrm{t}-1$ (periode sebelumnya)

c. Menghitung Abnormal Return

Menghitung abnormal return tiap saham pada hari pristiwa aksi bela Islam 2 Desember 2016. Abnormal return dihitung dengan rumus: ${ }^{24}$

$\mathbf{R T N}_{\mathrm{i} . \mathrm{t}}=\mathbf{R}_{\mathrm{i} . \mathrm{t}}-\mathbf{E}\left[\mathbf{R}_{\mathrm{i.t}}\right]$

Dimana:

$\mathrm{RTN}_{\mathrm{i} . \mathrm{t}}=$ Abnormal return sekuritas ke-i pada periode peristiwa ke-t.

$\mathrm{R}_{\mathrm{i} . \mathrm{t}} \quad=$ Return realisasian yang terjadi untuk sekuritas ke-i pada periode peristiwa ke t..

$\mathrm{E}\left[\mathrm{R}_{\mathrm{i} . \mathrm{t}}\right]=$ Return ekspektasian sekuritas ke-i untuk periode peristiwa ke-t.

${ }^{23}$ Moch Khusnul Fiton, 2014, Analisis Penngaruh Pelantikan Kabinet Kerja Presiden Joko Widodo Pada 27 Oktober 2014 Terhadap Reaksi Pasar Saham (Studi Kasus Pada Saham Yang Terdaftar LQ 45 di BEI), Skripsi, Universitas Malik Ibrahim Malang, Un-publised, 43.

${ }^{24}$ Hartono, Jogiyanto. Metodologi Penelitian Bisnis; Salah Kaprah dan Pengalaman-pengalaman. Yogyakarta: BPFE, 2004, 667. 
d. Menghitung Average Abnormal Return (ARR)

Pengujian adanya abnormal return tidak dilakukan untuk tiap-tiap sekuritas, tetapi dilakukan secara agregat dengan menguji rata-rata return taknormal seluruh sekuritas secara cross-section untuk tiap-tiap hari di periode peristiwa, dengan menggunakan rumus sebagai berikut: ${ }^{25}$

$\operatorname{RRTN}_{t}=\frac{\sum_{i=1}^{k} \operatorname{RTN}_{i t}}{k}$

Dimana:

$\mathrm{RRTN}_{\mathrm{t}}=$ Rata-rata return taknormal (average abnormal return) pada hari ke-t.

$\mathrm{RTN}_{\mathrm{i}, \mathrm{t}}=$ Return taknormal (abnormal return) untuk sekuritas ke-i pada hari ke-t.

$\mathrm{K}=$ Jumlah sekuritas yang terpengaruh oleh pengumuman peristiwa.

2. Menghitung Trading Volume Activity (TVA)

Menurut Suryawijaya dan Setiawan Trading Volume Activity merupakan suatu instrumen yang dapat digunakan untuk melihat reaksi pasar modal terhadap informasi melalui parameter pergerakan aktivitas volume perdagangan di pasar modal $^{26}$. TVA adalah perbandingan antara jumlah saham yang diperdagangkan pada waktu tertentu dengan jumlah saham perusahaan yang beredar pada periode tertentu. $^{27}$

Untuk menghitung aktivitas volume perdagangan saham digunakan persamaan sebagai berikut:

$$
T V A_{i t} \frac{\text { Saham perusahaan i yang diperdagangkan pada waktu } \mathrm{t}}{\text { Saham perusahaan iyang beredar di BEI pada waktu } \mathrm{t}}
$$

\section{Teknik Analisis Data}

Untuk menguji hipotesis yaitu melihat dampak event studi (kejadian) 212 terhadap abnormal retur dan volume Trading activity digunakan uji beda rata-rata dua sampel Paired Sample t-Test yang merupakan uji statistik parametrik. Paired Sample t-Test digunakan untuk menguji apakah dua sample yang berhubungan atau

\footnotetext{
${ }^{25}$ Hartono. Jogiyanto. Metodilogi Penelitian.....................30

${ }^{26}$ Suryawijaya, Marwan Asri, dan Faizal Arief Setiawan, 1998, Reaksi Pasar Modal terhadap Peristiwa Politik dalam Negeri (Event Studies pada Peristiwa 27 Juli 1996), KELOLA, Vol. VII, No. 18

${ }^{27}$ Djoko Susanto \& Agus Sabardi, 2010, Analisis Teknikal Di Bursa Efek Edisi Kedua, Yogyakarta: UPP STIM YKPN, 41.
} 
berpasangan berasal dari populasi yang mempunyai mean yang sama atau tidak. ${ }^{28}$ Atau uji $\mathrm{T}$ berpasangan digunakan untuk membandingkan rata-rata dua variabel dalam satu kelompok. Perhitungan dilakukan dengan cara mencari perbedaan antara nilainilai dua variabel untuk masing-masing kasus dan kemudian

\section{HASIL \& PEMBAHASAN \\ a. Deskripsi Data Penelitian}

Penelitian event studies ini bertujuan untuk mengetahui reaksi pasar pada saham perusahaan-perusahaan yang terdaftar di JII (Jakarta Islamic Index) terhadap adanya peristiwa aksi bela Islam 2 Desember (Aksi 212) Tahun 2016 dengan melihat Average Abnormal Return (AAR) dan Trading Volume Activity (TVA) yang diamati selama lima belas hari periode pengamatan di sekitar peristiwa aksi 212 , yaitu pada $t_{-7}, t_{0}$, dan $t_{+7}$. Obyek dalam penelitian ini adalah saham syariah yang terdaftar di Jakarta Islamic Index (JII) yang di dalamnya terdapat 7 perusahaan manufaktur dan 19 perusahaan non manufaktur.

Dua variabel diteliti dalam penelitian ini yaitu abnormal return saham syari'ah sebelum dan sesudah aksi 212, dan variabel activity volume trading saham syari'ah sebelum dan sesudah aksi 212. Variabel abnormal return menunjukkan deviasi antara expected return dengan real return saham syari'ah. Adapun deskripsi data abnormal return sebelum dan sesudah aksi 212, dijelaskan dalam tabel 1 berikut ini.

Tabel 1. Hasil Statistik Deskriptif Average Abnormal

Return Periode Sebelum dan Setelah Aksi 212

\begin{tabular}{|l|r|r|r|r|r|}
\hline & \multicolumn{1}{|c|}{ N } & Minimum & Maximum & Mean & Std. Deviation \\
\hline AAR Sebelum & 26 &,- 018633 &, 008705 &,- 00417812 &, 008129336 \\
AAR Setelah & 26 &,- 010765 &, 011212 &, 00030969 &, 005195221 \\
Valid N (listwise) & 26 & & & & \\
\hline
\end{tabular}

Sumber: data sekunder diolah.

Tabel 1 tersebut di atas menunjukkan bahwa pada periode sebelum peristiwa, nilai average abnormal return yang terendah sebesar -0,018633, sedang setelah peristiwa 212 nilai average abnormal return terendah senilai -0,010765. Standar deviasi abnormal

${ }^{28}$ Christianus Sigit, Seri Belajar Kilat SPSS 18 (Yogyakarta: Andi, 2017), 70. 
return untuk masing-masing periode sebelum dan setelah peristiwa sebesar 0,008129336 dan 0,005195221 .

Hasil perhitungan analisis statistik di atas menunjukkan bahwa terjadi peningkatan average abnormal return setelah peristiwa, yaitu sebelum peristiwa dengan nilai 0,00417812 menjadi 0,00030969 setelah peristiwa terjadi. Hal ini menunjukkan bahwa pasar bereaksi positif terhadap peristiwa aksi bela Islam 2 Desember 2016 yang terjadi. Dari hasil perhitungan rata-rata abnormal return di atas menunjukkan bahwa informasi pengumuman peristiwa aksi bela Islam 2 Desember 2016 mendapat respon dari pelaku pasar.

Terjadi pergerakan saham menarik seputar aksi 212, yaitu menjelang aksi 212 (sekitar 2 hari menjelang aksi 212) abnormal return masih bergerak naik, dan terus naik sampai hari ke 4 dari aksi 212 baru megalami penurunan abnormal return. Untuk memberikan gambaran dijelaskan dalam gambar 1 berikiut ini:

\section{Gambar 1. Average Abnormal Return di JII Lima Belas Hari Pengamatan}

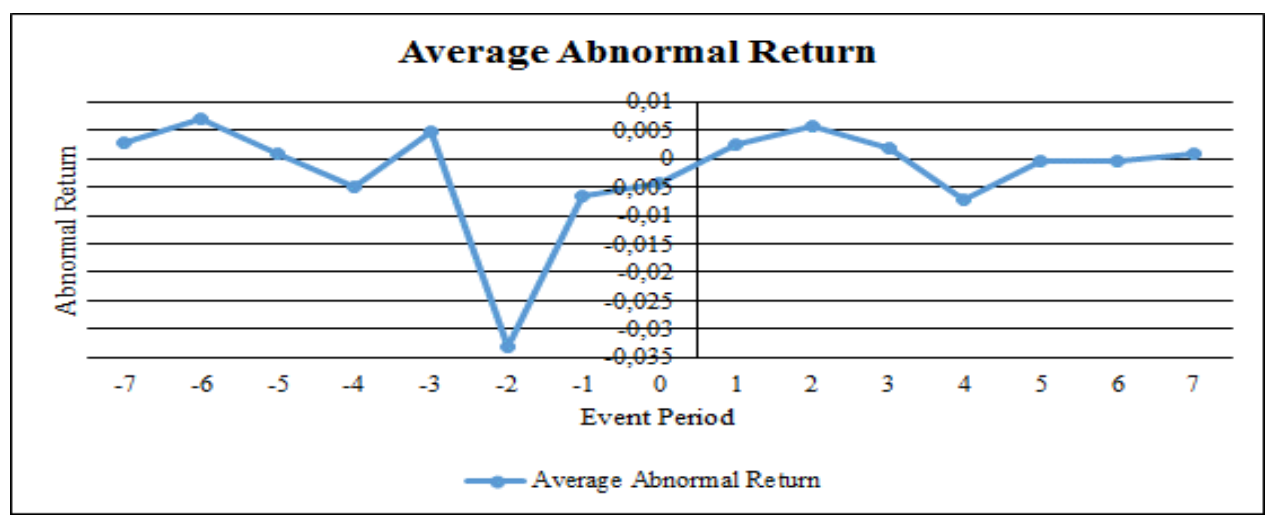

Sumber: data sekunder diolah, 2019

Gambar 1 tersebut diatas menjelaskan bahwa average abnormal return saham harian Jakarta Islamic Index menurun sampai pada saat H-2 menalami kenaikan hingga $\mathrm{H}+2$ setelah aksi 212. Hal itu menunjukkan terdapat dampak terhadap return saham sekitar 2 s/d 4 hari abnormal return saham. erjadi abnormal return positif pada hari ke 1 sampai dengan ke 3 dan ke 7 setelah aksi 212. Pada pengamatan hari ke 4, 5 dan 6 secara berturut-turut average abnormal return saham bernilai negatif. Begitu juga sebelum aksi 212, yaitu H-3 s/d H-7 juga mengalami fluktuasi dan cenderung menurunan (bernilai negatif). 
Hal serupa juga terjad pada Trading volume activity saham, menunjukjan gejala yang seruput, yaitu cenderung terdapat dampak aksi 212 terhadap volume perdagangan. Data Trading volume activity menunjukkan deviasi yang cukup tinggi yaitu sebesar 0,1768865 sebem aksi 212 dan sebesar 0.01373742 sesudah aksi 212. Untuk memberikan ggambaran lebih rinci, dijelaskan dalam tabel 2 berikut ini:

Tabel 2. Hasil Statistik Deskriptif Rata-rata Trading Volume ActivityPeriode Sebelum dan Setelah

\begin{tabular}{|l|c|c|c|c|c|}
\hline & $\mathrm{N}$ & $\begin{array}{c}\text { Minimu } \\
\mathrm{m}\end{array}$ & Maximum & Mean & $\begin{array}{c}\text { Std. } \\
\text { Deviation }\end{array}$ \\
\hline TVA Sebelim & 26 & .00973 & .08555 & .0384948 & .01768865 \\
\hline TVA Setelah & 26 & .01597 & .07321 & .0344461 & .01373742 \\
\hline Valid N (listwise) & 26 & & & & \\
\hline
\end{tabular}

Sumber: data sekunder diolah SPSS, 2019

Tabel 2 tersebut di atas menujukkan bahwa pada periode sebelum peristiwa, nilai rata-rata trading volume activity yang terendah sebesar 0,00973 , sedang nilai tertinggi sebesar nilai 0,08555 . Sedangkan setelah peristiwa terjadi, nilai rata-rata trading volume activity terendah senilai 0,01597, sedang nilai tertinggi sebesar 0,07321. Standar deviasi variabel rata-rata trading volume activity untuk masingmasing periode sebelum dan setelah peristiwa sebesar 0,01768865 dan 0,01373742.

Hasil perhitungan statistik analisis deskriptif rata-rata Trading Volume Activity (ATVA) terjadi penururnan rata-rata trading volum activity setelah peristiwa (event date), yaitu sebelum peristiwa senilai 0,0384948 menjadi 0,03444 setelah peristiwa. Penurunan tersebut mengindikasikan bahwa pasar bereaksi negatif terhadap peristiwa aksi 212.

Perubahan harian seluruh periode pengamatan trading volume activity bisa diamati pada perubahan rata-rata trading volume activity pada semua saham selama 15 hari periode pengamatan yang ditunjukkan oleh gambar 2 berikut ini: 


\section{Gambar 2. Rata-rata Trading Volume Activity Di JII}

\section{Lima Belas Hari Pengamatan}

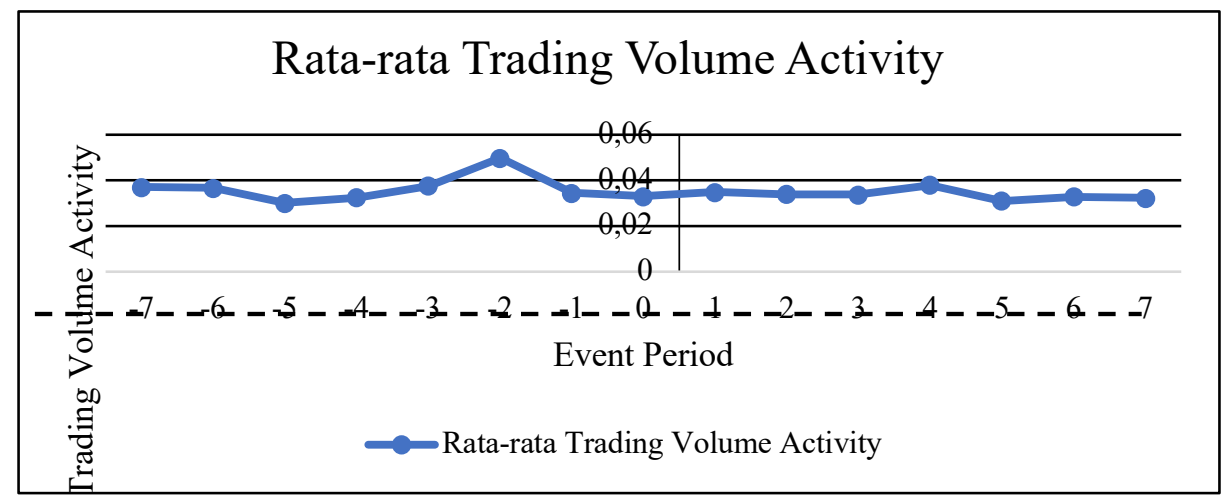

Sumber: Data Sekunder Diolah

Gambar 2 tersebut diatas menunjukkan bahwa rata-rata trading volume activity saham JII tidak terlalu mengalami pergerakan yang signifikan sebelum dan setelah peristiwa aksi 212 tahun 2016. Grafik menunjukkan bahwa terjadi peningkatan trading volume activity pada hari ke 4, namun volume perdagangan kembali mengalami penurunan pada hari ke 5, kemudian meningkat pada hari ke 6 dan kembali mengalami penurunan pada hari ke 7 setelah aksi 212. Perubahan rata-rata trading volume activity pada penelitian ini tidak besar, atau dapat dikatakan investor hanya melakukan transaksi saham dalam jumlah yang wajar lima hari setelah aksi 212 sehingga perubahannya relatif kecil.

\section{b. Pembahasan Hasil Uji Hipotesis}

1. Hasil Pengujian Abnormal Return Sebelum dan Setelah Aksi 212 Tahun 2016 Saham Syariah di JII

Event studies untuk membuktikan kalsifikasi teori efficiency market hypothesis dalam bentuk sensifitas reaksi pasar yang diproxi abnormal return dan trading volume activity saham syari'ah yang tergabung dalam Jakarta Islamic Index menunjukkan reaksi kuat dan lemah. Untuk abnormal rerturn menunjukkan reaksi kuat. Hal itu ditunjukkan dengan volatilitas abnormal return selama masa pengamatan 15 hari sebelum dan sesudah aksi 212. Untuk memberikan gambaran lebih rinci, dapat dilihat hasil perhitungan statistik paired sample t-test, berikut ini: 
Tabel 3. Hasil Uji Paired Samples Test Average Abnormal Return Pada Saham Syariah Yang Terdaftar Di JII

\begin{tabular}{|l|c|l|c|c|}
\hline \multicolumn{2}{|c|}{ Sebelum } & \multicolumn{2}{c|}{ Setelah } & Keterangan \\
\hline Mean & $-0,0041781$ & Mean & 0,0003097 & $\begin{array}{c}\text { Terdapat } \\
\text { perbedaan yang } \\
\text { signifikan }\end{array}$ \\
\hline Standar Deviasi & 0,008129 & Standar Deviasi & 0,0051952 & \\
T-hitung : -2,402 & & \\
Probabilitas : 0,024 & & \\
Tingkat Signifikansi : $5 \%$ & & \\
\hline
\end{tabular}

\section{Sumber: Data Sekunder Diolah.}

Hipotesis I yang menjelaskan "terdapat perbedaan average abnormal return antara sebelum dan sesudah aksi 212" tidak sanggup ditolak (hipotesis diterima). Hasil uji beda menunjukkan signifikansi sebesar 0,024<0,05, maka $\mathrm{H}_{01}$ ditolak dan $\mathrm{H}_{\mathrm{a} 1}$ diterima. Hasil pengujian tersebt mengandung makna bahwa terdapat perbedaan signifikan antara average abnormal return sebelum dengan setelah peristiwa aksi 212 pada saham syariah yang terdaftar di JII. Dari rata-rata (mean) dapat diketahui bahwa average abnormal return setelah aksi 212 lebih tinggi dari pada sebelum aksi 212. Hal mengandung makna bahwa, setelah aksi 212 dan pemerintah mampu mengendalikan keamanan secara politik maupun ekonomi ternyata mampu mengembalikan kepercayaan investor. Kondisi seperti itu dikehendaki oleh investor, sehingga mereka dapat melaksanakan investasi. Investor adalah pihak yang rasional, bentuk rasional investor ditunjukkan sikap kehatihatian investor, termasuk aksi-aksi lingkungan, sosial, politik, keamanan, dan event-event kontektual lain diperhatikan dan diperhitngkan oleh investor. Bentuk kepercayaan investor tersebut ditunjukkan dengan kecenderungan harga saham yang semakin naik, kendatipun volume trading tidak bergerak secara signifikan. Naiknya harga saham, meningkatkan abnormal return saham.

Hasil penelitian ini sesuai dengan hasil ppenelitian I Made Deva Hasdwi Putra dan I Gusti Ayu Made Dwija Putri. Penelitiannya menunjukkan bahwa berdasarkan hasil perhitungan statistik dapat disimpulkan bahwa pengumuman kemenangan Donald Trump menjadi Presiden Amerika Serikat merupakan suatu informasi yang 
membuat pelaku pasar merespon positif informasi aksi politik, termasuk di negara maju sekalipun sebagaimana ditunjukkan perbedaan average abnormal return sebelum dan sesudah pengumuman kemenangan Donald Trump menjadi presiden Amerika Serikat. ${ }^{29}$ Penelitian ini juga sesuai dengan Artiza Brilian Sari, bahwa terdapat perbedaan abnormal return sebelum dan sesudah stock split. ${ }^{30}$

\section{Trading Volume Activity Sebelum dan Setelah Aksi 212 Saham di JII}

Pengujian kedua event studies adalah membuktikan secara empiris apakah aksi 212 direspon oleh investor dalam hal ini volatilitas trading volume activity (aktivitas volume perdagangan) pada periode sebelum dan setelah aksi 212. Hasil perhitungan statistik menunjukkan bahwa tidak terdapat perbedaan rata-rata trading volume activity. Untuk memberikan secara lebih rinci ditunjukkan hasil pengolahan Paired Sample T-test, sebagai dalam tabel 4 berikut ini:

Tabel 4. Hasil Uji Paired Samples Test untuk Rata-rata Trading Volue Activity Pada Saham Syariah Yang Terdaftar Di JII

\begin{tabular}{|l|c|l|c|c|}
\hline \multicolumn{2}{|c|}{ Sebelum } & \multicolumn{2}{c|}{ Setelah } & Keterangan \\
\hline Mean & 0,03849 & Mean & 0,03444 & $\begin{array}{c}\text { Tidak terdapat } \\
\text { perbedaan yang } \\
\text { signifikan }\end{array}$ \\
\hline Standar Deviasi & 0,017689 & Standar Deviasi & 0,01373 & \\
T-tabel : 2,060 & & \\
Probabilitas : 0,075 & & \\
Tingkat Signifikansi : 5\% & & \\
\hline
\end{tabular}

\section{Sumber: Data Sekunder Diolah}

Hipotesis kedua yang diuji dalam peneitian ini adalah terdapat "perbedaan rata-rata trading volume activity (aktivitas volume perdagangan) pada periode sebelum dan setelah aksi 212". Hasil uji beda menunjukkan tidak signifikansi sebesar $0,075>0,05$, maka $\mathrm{H}_{02}$ diterima dan $\mathrm{H}_{\mathrm{a} 2}$ ditolak. Artinya hipotesis kedua

${ }^{29}$ I Made Deva Hasdwi Putra \& I Gusti Ayu Made Asri Dwija Putri, 2018, Analisis Reaksi Pasar Sebelum dan Sesudah Pengumuman Kemenangan Donald Trump Menjadi Presiden Amerika Serikat", EJurnal Akuntansi Universitas Udayana, Vol. 23, No. 1, Pp. 430, diakses pada 3 Desember, 2018, https://doi.org/10.24843/EJA.2018.v23.i01.p16.

${ }^{30}$ Artiza Brilian Sari, 2011, Pengaruh Stock Split Terhadap Abnormal Return Dan Trading Volume Activity Pada Perusahaan Yang Terdafar Di Bursa Efek Indonesia, Skripsi, Universitas Negeri Semarang,un-pubished, 74. 
tidak sanggup diterima (hipotesis ditolak). Dengan demikian dapat disimpulkan bahwa taksi 212 direspon oleh para investor dengan bersikap wait and Sea. Sikap menunggun investor membuat semakin menurun dan/atau stagnan trading dilantai bursa, terutama sedelah aksi 212. Wajar manakala rata-rata trading volume activity sebelum dan setelah peristiwa aksi 212 pada saham syariah perusahaan yang terdaftar di Jakarta Islamic Index menunjukkan tidak berbeda secara signifikan.

Hasil analisis deskriptif menunjukkan bahwa terjadi penurunan rata-rata trading volume activity setelah peristiwa (event date), yaitu sebelum peristiwa senilai 0,0384948 menjadi senilai 0,0344461 setelah peristiwa, sehingga menurunkan rata-rata trading volume activity sebesar 0,0040487 sebelum dan setelah aksi 212. Hal tersebut dapat disimpulkan bahwa selama periode lima belas hari investor cenderung mengantisipasi informasi yang masuk ke pasar dengan tidak berpengaruh pada isu-isu yang banyak beredar di media. Investor cenderung wait and Sea, sehingga volume perdagangan pada saham yang terdaftar di JII cenderung mengalami penurunan dan/atau stagnan setelah peristiwa aksi 212.

Hasil penelitian ini sesuai dengan penelitian yang dilakukan oleh Fransisko Purba dan Siti Ragil Handayani. Penelitiannya menunjukkan bahwa tidak terdapat perbedaan signifikan antara rata-rata trading volume activity sebelum dan sesudah peristiwa politik Pilkada DKI Jakarta 2017 Putaran Kedua. ${ }^{31}$ Penelitian juga sesuai dengan penelitian, yang menunjukkan bahwa tidak terdapat perbedaan rata-rata trading volume activity sebelum dan sesudah stock split. ${ }^{32}$

\section{SIMPULAN}

Mencermati hasil penelitian hasilnya cukup menarik, yaitu event studies yang merupakan pengujian teori efficiency market hypothesis bentuk lemah direspon investor secara kuat. Bentuk respons investor tersebut ditnjukkan dengan abnormal return saham syari'ah menunjukkan signifikan. Aksi 212 oleh organisasi Islam atas dugaan ujaran penistaan agama ternyata mempengaruhi variabilitas harga saham. Harga saham pada saat

${ }^{31}$ Fransisko Purba \& Siti Ragil Handayani, 2017, Analisis Perbedaan Reaksi Pasar Modal Indonesia Sebelum Dan Sesudah Peristiwa Non Ekonomi (Studi Pada Peristiwa Politik Pilkada DKI Jakarta 2017 Putaran Kedua), Jurnal Administrasi Bisnis (JAB), Vol. 51, No. 1. pp. 115.

${ }^{32}$ Artiza Brilian Sari, 2011, Pengaruh Stock Split Terhadap Abnormal Return Dan Trading Volume Activity Pada Perusahaan Yang Terdafar Di Bursa Efek Indonesia. Skripsi, Universitas Negeri Semarang, - uh-published. pp. 74. 
setelah kejadian aksi 212 menunjukkan kecenderung naik. Naiknya harga saham tersebut menaikkan abnormal return saham syari'ah. Hasil perhitungan statistik menunjukkan nilai signifikansi < 0,05, yaitu 0,024, yang berarti ada perbedaan average abnormal return antara 7 hari sebelum dan 7 hari setelah aksi 212. Ha itu, berbeda dengan bentuk respons investor yang ditunjukkan dengan trading volume activity yang menunjukkan tidak signifikan. Hal itu ditunjukkan hasil perhitungan statitik dimana signivikansi $>0,05$ yaitu sebesar 0,113. Hasil perhitungan yang tidak signifikan pada trading volume activity menunjukkan bahwa investor merespon aksi 212 dengan bersikap wait and see, mengingat terdapat risiko keamanan dan ekonomi pada aksi 212. Penelitian ini memiliki keterbatasan, terutama dalam hal pengukuran variabel serta belum tertangkapnya psikologis investor secara personal atas aksi sejenis 212. Hal itu karena, ukuran variabel lebih didasarkan pada proxi-nya. Rekomndasi bagi penelitian, didarankan untuk meng-ekplorer variabel psikologis investor berdasar persepsi personal terhadap aksi-aksi sejenis 212. 


\section{DAFTAR PUSTAKA}

Anisah, Nur, Lilik Pujiati dan Dian Sulistyo Widarti, 2017, Pengaruh Perubahan Harga Bahan Bakar Minyak terhadap Investasi Saham Perusahaan Transportasi Darat, EKSIS, Vol. 12, No.1.

Annisa Susanti, 2015, Analisis Pengaruh Kemenangan Pasangan Joko Widodo-Jusuf Kalla dalam Pilpres 2014 terhadap Abnormal Return dan Trading Volume Activity pada Kelompok Saham Indeks LQ-45, Skripsi, Universitas Negeri Yogyakarta,Un-publised.

Antariksa, B. 2005. Fenomena The Monday Effectdi Bursa Efek Jakarta. Simposium NasionalAkuntansi VII. Solo

Ambarwati. Sri Dwi Ari, 2005, Pengujian Eeek-Four, Monday, Fiday, dan Earning Mnagement Effect terhadap Return Saham, Jurnal Keuangan dan Perbankkan, Vol 13, No. 1.

Artiza Brilian Sari, 2011, Pengaruh Stock Split Terhadap Abnormal Return Dan Trading Volume Activity Pada Perusahaan Yang Terdafar Di Bursa Efek Indonesia, Skripsi, Universitas Negeri Semarang,-un-pubished, 74.

Aktas, H. and Oncu, S., 2006, The stock market reaction to extreme events: the evidence from Turkey, International Research Journal of Finance and Economics, Vol. 6, No. 6, pp. 78-85.

Bayuwati, Endah, 2010, Reaksi Return Perusahaan PMA dan PMDN terhadap Pengumuman Hasil Pemilu Legislatif, Pengumuman Hasil Pemilu Presiden dan Wakil Presiden, serta Pengumuman Hasil Pembentukan Kabinet 2009 (Studi pada Perusahaaan yang Terdaftar di BEI, Skripsi, Universitas Sebelas Maret Surakarta, uh-publised

Bodie, Zvi, Alex Kane, dan Alan J. Marcus, 2014, Manajemen Portofolio dan Investasi. Terjemahan oleh Romi Bhakti Hartarto dan Zuliani Dalimunthe, Jakarta: Salemba Empat.

Brown, S. and Warner, J., 1985, Using daily stock returns in event studies, Journal of Financial Economics, Vol. 14, No. 1, pp. 3-31.

Bechtel, M.M., 2009, The political sources of systematic investment risk: lessons from a consensus democracy, The Journal of Politics, Vol. 71, No. 2, pp. 661-677.

Christianus Sigit, 2017, Seri Belajar Kilat SPSS 18, Yogyakarta, Andi, 70.

Cahyaningdyah, D, 2005, Analisis Pengaruh Hari Perdagangan Terhadap Return Saham: Pengujian Week-Four Effect dan RogalskiEffect di Bursa Efek Jakarta, Jurnal Ekonomidan Bisnis Indonesia, Vol.20, No.2, hal.175-186. 
Chiu, C.L., Chen, C.D. and Tang, W.W., 2005, Political elections and foreign investor trading in South Korea's financial markets, Applied Economics Letters, Vol. 12 No. 11, pp. 673-677.

Dyl, Edward A, Maberly, Edwin D, 1988, A Possible Eplantion of The Weeken Effect, Financial Analysis Journal, Vol. 44, No. 33.

Djoko Susanto \& Agus Sabardi, 2010, Analisis Teknikal Di Bursa Efek Edisi Kedua, Yogyakarta, UPP STIM YKPN, 41.

Fabozzi, Frank J., 1999, Manajemen Investasi, Terjemahan oleh Tim Salemba Empat, Jakarta, Salemba Empat.

Fahmi, Irham, 2015, Manajemen Investasi Teori dan Soal Tanya Jawab Edisi 2. Jakarta: Salemba Empat.

Fiton, Moch Khusnul, 2015, Analisis Pengaruh Pelantikan Kabinet Kerja Presiden Joko Widodo pada 27 Oktober 2014 terhadap Reaksi Pasar Saham (Studi Kasus pada Saham yang Terdaftar LQ 45 di BEI, Skripsi, Universitas Malik Ibrahim Malang, Un-publised.

Ferguson, N., 2006, Political risk and the international bond market between the 1848 revolution and the outbreak of the First World War, Economic History Review, Vol. 59, No. 1, pp. 70-112

Feils, D.A., 2000, The impact of political risk on the foreign direct investment decision: a capital budgeting analysis, Emerging Economist, Vol. 45, No. 2, pp. 129-143.

Fransisko Purba \& Siti Ragil Handayani, 2017, Analisis Perbedaan Reaksi Pasar Modal Indonesia Sebelum Dan Sesudah Peristiwa Non Ekonomi (Studi Pada Peristiwa Politik Pilkada DKI Jakarta 2017 Putaran Kedua), Jurnal Administrasi Bisnis, Vol. 51, No. 1.pp. 115.

Ghozali, Imam, 2011, Aplikasi Analisis Multivariate dengan Program IBM SPSS 19 Edisi 5, Semarang, Badan Penerbit Universitas Diponegoro.

Hadi, Nor, 2015, Pasar Modal. Yogyakarta, Graha Ilmu.

Halim, Abdul, 2005, Analisis Investasi, Jakarta, Salemba Empat.

Halim, Abdul. 2015. Analisis Investasi dan Aplikasinya, Jakarta, Salemba Empat.

Hartono, Jogiyanto, 2004, Metodologi Penelitian Bisnis; Salah Kaprah dan Pengalaman-pengalaman. Yogyakarta, BPFE, 667.

Husnan, Suad, 2003, Dasar-dasar Teori Portofolio dan Analisis Sekuritas, Yogyakarta, AMP YKPN. 
Hidayat. R. Rustam. 2016. Pengarug Fakator-faktor Teknikal Tethadap Harga Saham Studi pada Hrga Saham IDX 30 di Bursa Efek Indonesia Periode 2012-2015, Jurnal Administrasi Bisnis Vol. 37, No. 1.

Hari Prasetyo, 2006, Analisis Pengaruh Hari Perdagangan Terhadap Return, Anbormal Return, Dan Volatilitas Return Saham (Studi Pada LQ 45 Periode JanuariDesember 2005), Tesis, Universitas Diponegoro, Un-plusished, 33

I Made Deva Hasdwi Putra \& I Gusti Ayu Made Asri Dwija Putri, 2018, Analisis Reaksi Pasar Sebelum dan Sesudah Pengumuman Kemenangan Donald Trump Menjadi Presiden Amerika Serikat", E-Jurnal Akuntansi Universitas Udayana, Vol. 23, No. 1, Pp. 430, diakses pada 3 Desember, 2018, https://doi.org/10.24843/EJA.2018.v23.i01.p16.

Irmayani, Ni Wayan Dian ,dan Ni Luh Putu Wiagustini, 2015, Dampak Stock Split terhadap Reaksi Pasar pada Perusahaan yang Terdaftar di Bursa Efek Indonesia, E-Jurnal Manajemen Unsoed 4, No. 10, (2015) - 26 September, 2018 https://ojs.unud.ac.id/index.php/Manajemen/article/view/14576.

Ismail, I. and Suhardjo, H., 2001, The impact of Domestic political events on an emerging stock market: the case of Indonesia, Proceedings of Asia Pacific Management Conference, pp. 235-262.

Jorion, P. and Geotzmann, W.N., 1999, Global stock markets in the twentieth century, Journal of Finance, Vol. 54, No. 3, pp. 953-980.

Katti, Siri Wardani Bakri, 2018, Pengaruh Peristiwa Politik (Pemilu Presiden dan Pengumuman Susunan Kabinet) terhadap Saham Sektor Industri di Bursa Efek Indonesia, CAPITAL, Vol. 1, No. 2.

Lestari, Dyah Putri Fuji, 2018, Dampak Britain Exit (DREAXIT) terhadap Abnormal Return dan Trading Volume Activity pada Indeks LQ-45, Jurnal Administrasi Bisnis (JAB) 55, No. 3, 2018.

Murtini, U. \& Halomoan.A.I. 2007. Pengaruh HariPerdagangan terhadap Return Saham:Pengujian Monday, Week-Four, danRogalski Effect di Bursa Efek Jakarta, Jurnal Riset Akuntansi dan Keuangan, Vol.3, No.1, hal.20-33.

Miller, 1988, The Modigliani-Miller Propositions after Thirty Years, Journal of Economic Perspective, Vol. 2, No. 4, pp.99-120.

Mian Sajid Nazir, Hassan Younus, Ahmad Kaleem \& Zeshan Anwar, 2014, Impact of political events on stock market returns: empirical evidence from Pakistan, Journal of Economic and Administrative Sciences, Vol. 30, No. 1, pp. 60-78.

Masood, O. and Sergi, B.S., 2008, How political risks and events have influenced Pakistan's stock markets from 1947 to present, Economic Policy in Emerging Economies, Vol. 1, No. 4, pp. 427-444. 
Mackinlay, A., 1997, Event studies in economics and finance, Journal of Economics Literature, Vol. 35, No. 1, pp. 13-35

Moch Khusnul Fiton, 2014, Analisis Penngaruh Pelantikan Kabinet Kerja Presiden Joko Widodo Pada 27 Oktober 2014 Terhadap Reaksi Pasar Saham (Studi Kasus Pada Saham Yang Terdaftar LQ 45 di BEI), Skripsi, Universitas Malik Ibrahim Malang, Un-publised, 43.

Prasetyo, Hari, 2006, Analisis Pengaruh Hari Perdagangan terhadap Return, Abormal Return, Dan Volatilitas Return Saham (Studi pada LQ 45 Periode Januari Desember 2005), Tesis, Universitas Diponegoro, un-pubised

Pratama, I Gede Bhakti, Ni Kadek Sinarwati dan Nyoman Ari Surya Dharmawan, 2018, "Reaksi Pasar Modal terhadap Peristiwa Politik (Event Studies pada Peristiwa Pelantikan Joko Widodo Sebagai Presiden Republik Indonesia Ke-7)", e-Journal S1 Ak Universitas Pendidikan Ganesha, Vol. 3, No. 1, 2015 - 28 September, 2018, https://ejournal.undiksha.ac.id/index.php/S1ak/article/ view/4754.

Peter, S., 2015, Explaining Short Run Performance of Initial Public Offerings in an Emerging Frontier Market: Case of Sri Lanka, International Journal of Economics, Business and Finance, Vol. 3, No. 1, pp 1-13.

Perera, W., \& Kulendran, N., 2016, Evaluation of Short-Run Market Performance and its Determinants Using Marginal Analysis and Binary Models: Evidence from Australian Initial Public Offerings, Journal of Insurance and Financia Management, Vol. 2, No. 6, pp. 1-29.

Qian Sun, Wison. H. S. Tong, Jing Tong, 2003, How Daes Government Ownership Affect Firm Performance? Evidence from China's Privatizations Experience, Journal of Business \& Accounting, Vol. 29, No. 1-2, pp. 1-27.

Rahmawati, Ika Yustina, 2016, Reaksi Pasar Modal dari Dampak Peristiwa Bom Plaza Sarinah terhadap Abnormal Return Perusahaan LQ 45 yang Terdaftar di BEI, Riset Akuntansi dan Keuangan Indonesia, vol.1, No. 2.

Santoso, Heri dan Luh Gede Sri Artini, 2015, Reaksi Pasar Modal Indonesia terhadap Pemilu Legislatif 2014 pada Indeks LQ45 DI BEI, E-Jurnal Manajemen Unud 4, No. 9, $2015 \quad$ - 2018 https://ojs.unud.ac.id/index.php/Manajemen/article/view/13566.

Sari, Artiza Brilian, 2011, Pengaruh Stock Split terhadap Abnormal Return dan Trading Volume Activity pada Perusahaan yang Terdaftar di Bursa Efek Indonesia, Skripsi, Universitas Negeri Semarang, uh-publise.

Sigit, Christianus, 2017, Seri Belajar Kilat SPSS 18, Yogyakarta, Andi.

Sulistiawan, Dedhy dan Liliani, 2007, Analisis Teknikal Modern pada Perdagangan Sekuritas, Yogyakarta, Andi. 
Suryawijaya, Marwan Asri, dan Faizal Arief Setiawan, 1998, Reaksi Pasar Modal terhadap Peristiwa Politik dalam Negeri (Event Studies pada Peristiwa 27 Juli 1996), KELOLA, Vol. VII, No. 18.

Setiyo, I \& Nurhatmini, E., 2003, Pengaruh Hari Perdagangan dan Exchange Rate terhadapReturn Saham di BEI, Jurnal Wahana, Vol.6, No.1.

Tandelilin, Eduardus, 2010, Portofolio \& Investasi Teori dan Aplikasi Edisi Pertama, Yogyakarta, Kanisius IKAPI.

Vong, A. P. I., \& Trigueiros, D., 2010, The short-run price performance of initial public offerings in Hong Kong: New evidence, Global Finance Journal, Vol. 21, No. 3, pp 253-261.

Yanti, Firga, 2012, Pengujian Abnormal Return Saham Sebelum dan Sesudah Peluncuran Indeks Saham Syariah Indonesia (ISSI), Jurnal Manajemen. Vol. 01, No. 01. 